\title{
Association between Plasmodium falciparum parasite index and renal function in children
}

\author{
A Umboh, MD; S Muljanto, MD; JS Wibisono, MD
}

\begin{abstract}
Background Falciparum malaria is an acute systemic disease that can cause multi organ disorders including in kidney. The aim of this study was to figure out the association between P.falciparum parasite index and renal function in children by measuring ureum, creatinine, and glomerular filtration rate (GFR).

Methods An analytic prospective study was conducted on all hospitalized falciparum malaria patients in the Department of Child Health, Manado Central General Hospital from November 2001February 2002. Low parasitemia was defined if P.falciparum found was $\leq 100 / 100$ fields and high parasitemia if $>1 / 1$ field. Data were analyzed by chi-square and student t-test.

Results Among 34 patients, there were 11 with high parasitemia and 23 with low parasitemia. There were 19 with increased ureum and 8 with increased creatinine. There was significant elevation of ureum in high parasitemia $(n=10)$ compared to that in low parasitemia patients $(n=9)$ with $p=0.004$. The increase of serum creatinine was found in 2 high parasitemia and in 6 low parasitemia patients $(p=0.611)$. Mean GFR was $107.63 \pm 30.62$ in high and $121.94 \pm 44.06$ in low parasitemia patients $(p=0.341)$.

Conclusion There was a significant association between P.falciparum parasite index and serum ureum. But there was no significant association between parasite index and creatinine or GFR [Paediatr Indones 2003;43:91-94].
\end{abstract}

Keywords: Plasmodium falciparum, parasitemia, ureum, creatinine, glomerular filtration rate

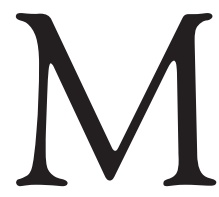

alaria is a disease caused by parasites, which has so far been an important social health problem in developing countries, including Indonesia. ${ }^{1}$ Falciparum malaria is an acute systemic disease which can cause changes of various body organs. The high density of parasites in blood in general is associated with pathological abnormalities in various organs including kidney. ${ }^{2}$ It is not clear whether the increase of urea nitrogen of the malarial patients is the answer to the renal function failure or the presence of another factor outside the kidney. There are very few detailed articles concerning the pathology and change in the renal function of malaria patients. Sowunmi et al found that all falciparum malaria patients with high parasite index had serim ureum and creatinine above normal. ${ }^{3}$

From several studies, it was said that the high density of Plasmodium falciparum parasites brings about the high incidence of renal function failure in non-immune individuals and there is a positive correlation between the high parasite index and the failure of renal function. ${ }^{4}$ According to Ahmad et al, renal function in children with acute malaria is associated with species and parasites index, but a negative correlation was detected between parasite index and clearance of endogenous creatinine. ${ }^{5}$ This study was conducted to figure out how far the P.falciparum parasite index in children could influence renal function by measuring serum ureum, creatinine, and glomerular filtration rate (GFR).

From the Department of Child Health, Medical School, Sam Ratulangi University-Malalayang Hospital, Manado.

Reprint requests to: Adrian Umboh, MD, Consultant Pediatrician, Department of Child Health, Medical School, Sam Ratulangi University, Malalayang Hospital, Manado, Indonesia. Tel. 62-431-821652, Fax. 62 431-859091.

Presented at the $12^{\text {th }}$ National Congress of Child Health, Bali June $30-$ July 4, 2002. 


\section{Methods}

This was an analytic prospective study, conducted at the Department of Child Health, Manado Central General Hospital, from November 2001 to February 2002. Subjects consisted of all children aged $>1$ month until 13 years with a diagnosis of falciparum malaria based on the detection of Plasmodium falciparum on blood smear or thick blood film and were grouped by sex and age. A detailed history was taken in each patient. This was followed by a thorough physical examination. Body length was measured in all patients. Serum ureum and creatinine were examined soon after diagnosis, before treatment was started, and then the GFR was calculated. Those with dehydration accompanied with clinical symptoms, hypovolemia/shock, a history of significant renal diseases, or a presence of urolithiasis were excluded from the study.

Levels of serum ureum based on age were grouped as normal and increased according to Hammond. ${ }^{6}$ Serum creatinine levels based on age were grouped as normal and increased according to Alatas. ${ }^{7}$ Glomerular filtration rate (GFR) was calculated based on the formula : GFR $=(\mathrm{kX} \mathrm{L}) / \mathrm{Pkr}$, where $\mathrm{L}$ was the body length in $\mathrm{cm}, \mathrm{Pkr}$ was the serum plasma/creatinine $(\mathrm{mg} / \mathrm{dl})$, and $\mathrm{k}$ was a constant which differs in various child ages (neonate up to 1 year: $\mathrm{k}=0.45$; children up to the age of 13 years: $k=0.55)$. GFR based on age were grouped as normal and decreased according to Alatas. ${ }^{7}$

P.falciparum parasite index was classified into two groups based on WHO ${ }^{8}$ which was modified into: low parasitemia if $>100$ P.falciparum were found in 100 microscope fields of vision, and high parasitemia if $>1$ P.falciparum were found in each microscope field of vision.

Data were analyzed statistically using chi-square and student t-test with a value of $\mathrm{p}<0.05$ considered as significant.

\section{Results}

There were 22 males and 12 females, 23 of them had low parasitemia and 11 had high parasitemia. No significant association was found between sex and P.falciparum parasite index as indicated in Table 1 .
Table 1. Distribution of sex based on P.falciparum PARASITE INDEX

\begin{tabular}{lccl}
\hline Sex & Low parasitemia & High parasitemia & Total \\
\hline Male & 13 & 9 & 22 \\
Female & 10 & 2 & 12 \\
Total & 23 & 11 & 34 \\
\hline
\end{tabular}

$\mathrm{X}^{2}=2.085, \mathrm{df}=1, \mathrm{p}=0.149$

Out of the 34 patients, 19 showed increased serum ureum level consisting of 10 with high parasitemia and 9 with low parasitemia (Table 2). There was a significant association between parasite index and a raise in serum ureum with $\mathrm{p}=0.004$.

Table 2. Association between P. falciparum parasite INDEX AND INCREASED OF SERUM UREUM

\begin{tabular}{llll}
\hline Ureum level & $\begin{array}{l}\text { Low } \\
\text { parasitemia }\end{array}$ & $\begin{array}{l}\text { High } \\
\text { parasitemia }\end{array}$ & Total \\
\hline Normal & 14 & 1 & 15 \\
Increased & 9 & 10 & 19 \\
Total & 23 & 11 & 34 \\
\hline
\end{tabular}

$\mathrm{X}^{2}=8.092, \mathrm{df}=1, \mathrm{p}=0.004$

Serum creatinine increased in 8 patients, 2 in those with high parasitemia and 6 with low parasitemia. No significant association was found between P.falciparum parasite index and the increase in serum creatinine as indicated in Table 3.

Table 3. Association between P. falciparum parasite INDEX AND INCREASE OF SERUM CREATININE

\begin{tabular}{llll}
\hline Creatinine level & $\begin{array}{l}\text { Low } \\
\text { parasitemia }\end{array}$ & $\begin{array}{l}\text { High } \\
\text { parasitemia }\end{array}$ & Total \\
\hline Normal & 17 & 9 & 26 \\
Increased & 6 & 2 & 8 \\
Total & 23 & 11 & 34 \\
\hline
\end{tabular}

$X^{2}=0.258, d f=1, p=0.611$

GFR was decreased in 1 patient with low parasitemia and 1 with high parasitemia. As indicated in Table 4, there was no significant association between P.falciparum parasite index and GFR. The mean value of GFR in patients with high parasitemia and in those with low parasitemia were not significantly different $(p=0.341)$, that was also the same with the mean of creatinine level, as presented in Table 5. 
Table 4. Association between P. falciparum parasite INDEX AND DECREASE OF GFR

\begin{tabular}{llll}
\hline GFR level & $\begin{array}{l}\text { Low } \\
\text { parasitemia }\end{array}$ & $\begin{array}{l}\text { High } \\
\text { parasitemia }\end{array}$ & Total \\
\hline Normal & 22 & 10 & 32 \\
Decreased & 1 & 1 & 2 \\
Total & 23 & 11 & 34 \\
\hline $\mathrm{X}^{2}=0.302, \mathrm{df}=1, \mathrm{p}=0.582$ & &
\end{tabular}

Table 5. Ureum, creatinine levels, and GFR value in ASSOCIATION WITH P.FALCIPARUM PARASITE INDEX

\begin{tabular}{lcll}
\hline & $\mathbf{N}$ & Mean & $\mathbf{p}$ \\
\hline $\begin{array}{l}\text { Ureum level in :* } \\
\text { Low parasitemia }\end{array}$ & 23 & $19.93 \pm 7.62$ & 0.027 \\
High parasitemia & 11 & $27.33 \pm 10.68$ & \\
\hline Creatinine level in :** & & & \\
Low parasitemia & 23 & $0.58 \pm 0.18$ & 0.727 \\
High parasitemia & 11 & $0.61 \pm 0.26$ & \\
\hline GFR value in : ${ }^{* *}$ & & & \\
Low parasitemia & 23 & $121.94 \pm 44.06$ & 0.341 \\
High parasitemia & 11 & $107.63 \pm 30.62$ & \\
\hline${ }^{*}$ and ${ }^{* *}$ in units of $\mathrm{mg} / \mathrm{dl}$ & & \\
${ }^{* * *}$ in units of $\mathrm{ml} / \mathrm{minute} / 1.73 \mathrm{~m}^{2}$ & &
\end{tabular}

\section{Discussion}

So far a lot of reports had been published concerning malaria in Indonesia and various methods of its elimination. A great part of Java and Bali have been free from the transmission of malaria, whereas the morbidity in North Sulawesi in 1997 was still 25.33 \%. ${ }^{9}$ Tropical malaria which is caused by Plasmodium falciparum is a systemic disease which can lead to complex pathophysiological changes and involves many organs. The underlying mechanism causing these pathophysiological changes has not been fully elucidated. It has been suggested that disturbances in the renal microcirculation are responsible for acute renal failure. ${ }^{10,11}$

Acute infection of Plasmodium falciparum causes abnormality on the membrana basalis and mesangial of the kidney. Using fluorescence antibody technique, malaria antigens are detected, which cause the formation of immune complex with the consequence of the occurrence of uremia, oligouria, and proteinuria, ${ }^{2,12}$

The knowledge of renal function is still poor compared with that of anemia and cerebral complication in patients with malaria. The pre renal factors i.e., the increase of body temperature which causes a loss of fluid and dehydration, can obstruct renal perfusion, so that renal hypoxia occurs with the consequence of the occurrence of acute tubular necrosis. This, along with changes in glomerulus caused by immune-complex, constitute as important factors for the occurrence of acute renal failure in individuals who were not immune. There was a positive correlation between parasite index and failure of renal function. 4,13

The increase in ureum and creatinine levels in falciparum malaria were usually caused by pre renal factors. ${ }^{14}$ Harinasuta and Dunnag stated that $50 \%$ of patients with severe falciparum malaria showed a raise in ureum and creatinine levels which was usually due to the pre renal factors. Only 3-5\% was caused by renal factors, which could be either acute tubular necrosis or acute glomerulonephritis. ${ }^{14,15}$

Renal disturbances were presumed to be caused by the presence of anoxia because of capillary obstruction which result in the lowering of glomerulus filtration. Clinically, a phase of oligouria or polyuria may occur. ${ }^{16}$ In small children and infants the condition of oligouria is very rare, but the presence of an increase in ureum level often occurs early resulting from dehydration and ureum level will be normal if rehydration is conducted. Dehydration could happen because of vomitting or sweating. ${ }^{17}$ Pre renal azotemia occurs secondary to a decrease in blood volume as a result of water and/or salt depletion in a number of cases or an increase in protein catabolism associated with pyrexia, or a combination of these factors. ${ }^{18}$

In this study a significant association was found between Plasmodium falciparum parasite index and the increase in serum ureum level $(\mathrm{p}<0.05)$. In accordance with the references as have been mentioned above, the increase in serum ureum in this study appeared early, namely a moment after the diagnosis. This might be caused by pre renal factors, where in general, a child who has malaria will have high fever accompanied with vomitting. ${ }^{17}$ In this study, we found 27 out of 34 children with prolonged fever ( $>5$ days) and 28 had vomitting.

In this study, no significant association was found between P.falciparum parasite index and the increase in serum creatinine level $(\mathrm{p}>0.05)$. This was consistent with the study conducted by Ahmad et al, who found a negative correlation between parasite index and endogen creatinine clearance. ${ }^{5}$ 
The GFR value and mean GFR in this study did not indicate a significant association with the parasite index of Plasmodium falciparum. This was consistent with the increase in serum creatinine which was statistically insignificant. As indicated by Kim et al, the increase of creatinine level above 2 SD only indicated the presence of failure in renal function. ${ }^{19}$ According to Alatas, the best way to get the real GFR was by creatinine clearance value.?

The limitation of this study was that the number of patients was low. According to the $\mathrm{WHO}$, there was a association between parasite index and severity of the disease as well as renal function failure, in which serum creatinine would increase since the appearance of the first symptom. ${ }^{4,13,16}$. It needs further study to evaluate the association between renal function and P.falciparum parasite index in children with more number of patients.

In conclusion, there was a significant association between $P$. falciparum parasite index and serum ureum level. However, there was no significant association between parasite index with serum creatinine and GFR. Further investigation is needed in Indonesia with more number of patients.

\section{References}

1. Zulkarnain I. Upadate on malaria. Acta Med Ind 1997;29:161 - 6 .

2. WHO. Pathophysiology with special reference to falciparum malaria. The clinical management of acute malaria. WHO Regional Office for South East Asia. New Delhi; 1990. p. 9-17.

3. Sowunmi A. Renal function in acute malaria falciparum. Arch Dis Child 1996;74:293-8.

4. Weber MW, Boker K, Hortmann RD, Ehrich JHH. Renal failure is a common complication in non immune Europeans with plasmodium falciparum malaria. Trop Med Parasitol 1989;42:115-8.

5. Ahmad SH, Danish T, Fandi MMA, Ahmad AJ, Fakir S, Khan AS. Renal function in acute malaria in children. J Trop Ped 1989;35:291-4.

6. Hammond KB. Normal biochemical \& hematologic values. In: Hay WW, Groothuis JR, Hayward AR, Levin
MJ, editors. Current pediatric diagnosis and treatment. $13^{\text {th }}$ ed. Stamford, Connecticut: Appleton \& Lange; 1997. p. 1130.

7. Alatas $\mathrm{H}$. Evaluasi fungsi ginjal. In: Alatas $\mathrm{H}$, editor. Nefrologi anak, vol. 1. Jakarta : IDAI; 1993. p. 33-50.

8. Purwaningsih S. Diagnosis malaria. In: Harijanto PN, editor. Malaria, epidemologi, patogenesis, manifestasi klinis \& penanganan. Jakarta: EGC; 2000. p. 185-93.

9. Laihad FJ, Gunawan S. Malaria in Indonesia. In: Harijanto PN, editor. Malaria, epidemologi, patogenesis, manifestasi klinis \& penanganan. Jakarta EGC; 2000. p. 17-25.

10. Mehta KS, Halankar AR, Makwana PD, Torane PP, Satija PS, Shah VB. Severe acute renal failure in malaria. J Postgrad Med 2001;47:24-6.

11. Musyawarah, Albar H, Rauf S. Nefropati malaria pada anak. J. Med Nus 1997;18:52-7.

12. Barsoum RS. Malarial acute renal failure. J Am Soc Nephrol 2000;11:2147-54.

13. Mashaal H. Physician's guide to effective management of cases of malaria. 1993. p. 13-5.

14. Tambajong EH. Patobiologi malaria. In: Harijanto PN, editor. Malaria, epidemiologi, patogenesis, manifestasi klinis \& penanganan. Jakarta : EGC; 2000. p. 104-6.

15. Harinasuta T, Dunnag D. The clinical features of malaria. In: Wernsdorfer WH, Mc Gregor SI, editors. Malaria principles and practice of malariology, vol. 1. Edinburg London Melbourne and New York: Churchill Livingstone; 1988. p. 721-3.

16. Harijanto PN. Gejala klinik malaria berat. In: Harijanto PN, editor. Malaria, epidemiologi, patogenesis, manifestasi klinis \& penanganan. Jakarta: EGC; 2000. p. 166-84.

17. WHO. Severe falciparum malaria. Trans R Soc Trop Med Hyg 2000;94(suppl 1):15-28.

18. Flecther KA, Gilles HM. The chemical pathology of malaria. In: Wernsdorfer WH, Mc Gregor SI, editors. Malaria principles and practice of malariology, vol. 1. Edinburg London Melbourne and New York: Churchill Livingstone; 1988. p. 652-7.

19. Kim Y. Michael AF, Tarshih P. Infection and nefritis. In: Chester M, Edellman Jr, editors. Pediatric kidney disease. $2^{\text {nd }}$ ed. Boston Toronto London: Little Brown and Company; 1992. p. 1569-78. 